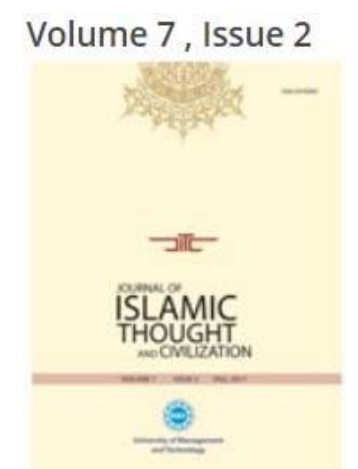

Journal of Islamic Thought and Civilization (JITC)

Volume 7, Issue 2, Fall 2017

ISSN: 2075-0943, EISSN: 2520-0313

Journal DOI: https://doi.org/10.29145/jitc

Issue DOI: https://doi.org/10.29145/jitc/72

Homepage: https://www.umt.edu.pk/jitc/home.aspx

Journal QR Code:

\title{
Article: “The Days of God”- Muhammad Iqbal’s Conception of Time and History
}

Author(s): $\quad$ Carimo Mohomed

Online Published: $\quad$ October 2017

Article DOI: $\quad$ doi.org/10.29145/2017/jitc/72/070201

Article QR Code:

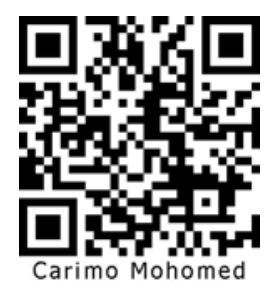

To cite this article: Mohomed, Carimo. "The days of God - Muhammad Iqbal's conception of time and history.” Journal of Islamic Thought and Civilization 7, no. 2 (2017): 1-17. DOI: https://doi.org/10.29145/2017/jitc/72/070201

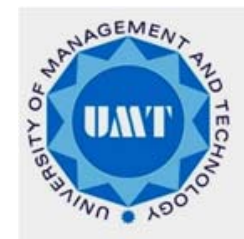

A publication of the

Department of Islamic Thought and Civilization

School of Social Science and Humanities

University of Management and Technology

Lahore 


\title{
\&
}

“The Days of God"- Muhammad Iqbal's Conception of Time and History

\author{
Carimo Mohomed \\ Centre of Religious History Studies, \\ Catholic University of Portugal
}

\begin{abstract}
Muhammad Iqbal (1877-1938) was a prolific writer who authored many works covering various fields and genres such aspoetry, philosophy, and mysticism. He expressed his ideas in many forms and this paper, using his works, especially The Reconstruction of Religious Thought in Islam, deals with the question of time and history in his thought, particularly how he distinguished 'the past' from 'the present' and 'the future,' and how he constructed their interrelationships.
\end{abstract}

Keywords: time, history, Muhammad Iqbal, Islam, Qur'ān

\section{Introduction}

As it was debated in the workshop Breaking up time: settling the borders between the present, the past and the future (7-9 April 2011) ${ }^{1}$ since the birth of modernity history has presupposed the existence of 'the past' as its object, yet the concept of 'the past' and the distinction between the categories of 'the past,' 'the present' and 'the future' have seldom been reflected upon within the boundaries of the discipline. Indeed several 'time-sensitive' historians ${ }^{2}$ and philosophers of history ${ }^{3}$ have observed that the question of time has largely been omitted from its agenda. However, taking a certain definition of 'the past' for granted is folly, if we consider that throughout history different cultures and societies have conceived of 'the past' and the boundaries between 'past, 'present' and 'future' in very different ways. We have only to look at the various conceptions of time that are used in law (legal time), history (historical time) and religion (religious time) to see how the Western notion of 'the past' changes depending on the context in which it is being discussed. ${ }^{4}$

\footnotetext{
${ }^{1}$ For further details, please refer to http://www.frias.uni-freiburg.de/de/das-institut/archivfrias/school-of-history/veranstaltungen/PresentPastFuture, last accessed $18^{\text {th }}$ June 2017.

${ }^{2}$ Lynn Hunt, Measuring Time, Making History (Budapest: Central European University Press, 2008); Lucian Hölscher, Semantik der Leere. Grenzfragen der Geschichtswissenschaft (Göttingen: Wallstein Verlag, 2009).

${ }^{3}$ Berber Bevernage, "We Victims and Survivors Declare the Past to be in the Present': Time, Historical (In) justice and the Irrevocable" (Ph.D. Thesis, Ghent: University of Gent, Faculty of Arts and Philosophy, 2009); Berber Bevernage, "Time, Presence, and Historical Injustice," in History and Theory 47 (May 2008): 149-167.

${ }^{4}$ Also illuminating are the debates between physicists, mathematicians, philosophers and others about what is Time. For a brief overview on this, please refer to Palle Yourgrau, A World without Time: the Forgotten legacy of Gödel and Einstein (New York: Basic Books, 2004) and the Review by John Stachel in Notices of the American Mathematical Society, vol 54, no. 7 (August
} 


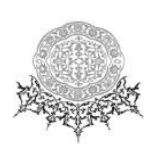

While it is widely accepted that cultures have different orientations dominant in different periods of time, it is rarely investigated in history how these temporal orientations evolve and develop; whether they succeed one another or co-exist with each other.

François Hartog's thesis that Western thinking about history is characterized by a succession of three 'regimes of historicity' - from a past-orientation till the French Revolution, succeeded by a future-orientation till the 1980's, followed by a present-orientation since then - has hardly been empirically tested. ${ }^{5}$ Therefore, questions about theunity, the dominance, the spatial extensions, the transfers, the transformation and the implications of these 'time regimes' are still open to both conceptual and empirical analysis.

It is about time for historians and philosophers of history to begin analyzing how cultures in general and historians in particular actually distinguish 'the past' from 'the present' and 'the future,' and how their interrelationships are constructed, either with the aim to distinguish between them simply as a matter of passive 'recognition' or 'observing' what is 'natural' and 'undeniable,' or with the involvement of a more active stance in which social actors create and recreate these divisions? Can we claim to know precisely how 'present' social and cultural phenomena turn into (orcome to be perceived/recognized as) past phenomena? Do historians reflect on the nature of the borders that separate these temporal dimensions? The familiar problem of defining the boundaries of 'contemporary history' usefully illustrates the uncertainty about 'time' within the discipline of history, that is does the long standing taboo on contemporary history not, among other things, betray an underlying unwillingness to probe the limits that separate 'past' and 'present'?

Recently, however, there have been signs, within the fields of history and philosophy of history, of an increasing interest in the notion of 'time,' following in the footsteps of Reinhart Koselleck ${ }^{6}$ a growing number of historians have started

2007): 861-868; Espen Hammer, Philosophy and Temporality from Kant to Critical Theory (Cambridge, UK: Cambridge University Press, 2011); and Brian FAY, "Hammer Time," in History and Theory 52 (February 2013):1-19; Tyrus Miller, (ed.) Given World and Time: Temporalities in Context (Budapest: CEU Press, 2008); Nitzan Lebovic, "The Sovereignty of Modern Times: Different Concepts of Time and the Modernist Perspective," in History and Theory 49 (May 2010): 281-288; David Hoy, The Time of our Lives: A Critical History of Temporality (Cambridge, Mass., and London: MIT Press, 2009); and Charles Bambach, "The Time of the Self and the Time of the Other," in History and Theory 50 (May 2011): 254-269.

${ }^{5}$ Fançois Hartog, Régimes d'Historicité, Présentisme et Expériences du Temps (Paris: Le Seuil, 2003).

${ }^{6}$ Reinhart Koselleck, Zeitschichten: Studien zur Historik (mit einem beitrag von Hans-Georg Gadamer). (Frankfurt: Suhrkamp Verlag, 2000); Reinhart Koselleck, Futures Past: On the Semantics of Historical Time, transl. Keith Tribe, (Cambridge, Mass.: MIT Press, 1985); and Reinhart 


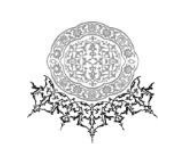

historicizing time-conceptions which has been taken for granted formerly. In the field of philosophy of history, the relationship between the past and the present has recently moved to a central stage in the debates about 'presence,' 'distance,' 'trauma' and 'historical experience' - sometimes leading to new forms of 'presentism,' as in the case of 'memory studies' and in radical constructivism. Independently some postcolonial theorists and anthropologists have added momentum to the growing interest in the notion of 'time' by deconstructing the' time of history' as specifically 'Western' time.

Against this background it seems worthwhile to make a connection between thehistorical and the philosophical debates about the temporal distinctions between 'past', 'present' and 'future.' What have so far been lacking is the comparative analyses of the variety of ways in which historians and historical actors have been breaking up time in practice. Often 'the past' is somehow supposed to 'break off' from 'the present' by itself. Both historians and philosophers have emphasized the role played by the catastrophic political ruptures, for example revolutions and major wars, in 'breaking up time.' However, the effects of these 'transformative events ${ }^{8}$ on notions of temporality have hardly been studied in a comparative perspective and as performative events. Of course critical reflexion on historical time should not be reduced to the writing of new (social, cultural) histories of time; it should also include a focus on the way in which time is implied in, and constitutive of, our discipline. François Hartog has, for example, argued that terms such as 'past,' 'present' and 'future' are always invested with a different value in different regimes of historicity.

This observation suggests that historians must ask whether historical time is a neutral medium or an analytical tool that it is often believed to be, or whether it is

Koselleck, The Practice of Conceptual History: Timing History, Spacing Concepts, transl. Todd Samuel Presner et al. (Stanford: Stanford University Press, 2002).

${ }^{7}$ For further details on this, please refer to Dipesh Chakrabarty, Provincializing Europe. Postcolonial Thought and Historical Difference (Princeton: Princeton University Press, 2000); Sebastian Conrad, "What Time is Japan? Problems of Comparative (Intercultural) Historiography," in History and Theory vol. 38 (1999): 67-83; Helge Jordheim, "Against Periodization: Koselleck's Theory of Multiple Temporalities," in History and Theory 51 (May 2012): 151-171; Anita Kasabova, "Memory, Memorials, and Commemoration," in History and Theory 47 (October 2008): 331-350; John Zammito, "Koselleck's Philosophy of Historical Time(s) and the Practice of History," in History and Theory 43 (February 2004): 124-135.

${ }^{8}$ Doug McAdam, and J. R. Sewell, William H., "It's About Time: Temporality in the Study of Social Movements and Revolutions," in Ronald Aminzade, et. al., Silence and Voice in the Study of Contentious Politics (Cambridge: Cambridge University Press, 2001): 80-126. 


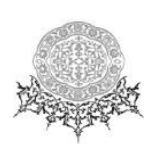

actually inherently political. Do historians engage in a 'politics of time,' as the anthropologist Johannes Fabian has for example argued to be the case in his field?

This paper, using Muhammad Iqbal's works, especially The Reconstruction of Religious Thought in Islam will deal with the question of Time, History, and historical time in his thought, particularly how he actually distinguished 'the past' from 'the present' and 'the future' and how their interrelationships were constructed.

\section{Time and History in Muhammad Iqbal}

Born in Sialkot, now a days Pakistan, on $9^{\text {th }}$ November 1877 , in the same year that the Muhammadan Anglo-Oriental College, at Aligarh, started to function, Muhammad Iqbal (1877-1938) was a prolific writer, authoring many works covering various fields and genres, including poetry, philosophy, and mysticism, which should be viewed as a unity. His ideas were expressed through many forms and even Anne Marie Schimmel, one of the most important western specialists on Iqbal, acknowledged the difficulty in constructing a system based on his work.

Originally published in Lahore, in 1930, as Six Lectures on the Reconstruction of Religious Thought in Islam, and then revised and added with the lecture "Is Religion Possible?" and an index, this book was then published under the title The Reconstruction of Religious Thought in Islam, ${ }^{10}$ in London, in 1934.

Muhammad Iqbal began by saying in the "Preface" that the Qur'ān is a book which emphasized 'deed' rather than 'idea' and that the modern man and the modern mind made a demand for a scientific form of religious knowledge and not the perpetuation of methods which were created for generations possessing a cultural outlook different from their own, that is of the $20^{\text {th }}$ century. He, Muhammad Iqbal, tried, with the lectures, to meet, even though partially, that urgent demand by attempting to reconstruct Muslim religious philosophy with due regard to the philosophical traditions of Islam and the more recent developments in the various domains of human knowledge, at a moment quite favourable for such an undertaking, since Classical Physics had learned to criticize its own foundations. As a result of that criticism, the kind of materialism which it originally necessitated was rapidly disappearing; and the day was not far off when religion and science may discover hitherto unsuspected mutual harmonies. However, Iqbal was cautious, remembering that there was no such thing as finality in philosophical thinking. As knowledge advanced and fresh avenues of thought were opened, other views, and probably sounder views than those set forth in those lectures, were possible. His duty

\footnotetext{
${ }^{9}$ Johannes Fabian, Time and the Other. How Anthropology Makes its Object (New York: Columbia University Press, 2002).

${ }^{10}$ Muhammad Iqbal, The Reconstruction of Religious Thought in Islam (New Delhi: Kitab Bhavan, 1998).
}

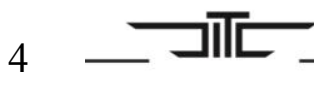

JOURNAL OF ISLAMIC THOUGHT AND CIVILIZATION 


\section{사}

was to carefully watch the progress of human thought, and to maintain an independent critical attitude towards it.

Influenced by his Islamic heritage and by western philosophy (Hegel, Bergson, Fichte, Nietzsche), Iqbal developed his own synthesis and interpretation of Islam, in response to the socio-historical conditions and events of his epoch, ${ }^{11}$ something visible throughout his lectures.

In "The philosophical test of the revelation of religious experience,"12 and citing Alfred North Whitehead (1861-1947), Iqbal postulated that nature was not a static fact situated in an a dynamic void, but a structure of events possessing the character of a continuous creative flow which thought cuts up into isolated immobilities out of whose mutual relations arise the concepts of space and time, allowing us to see how modern science utters its agreement with the criticism of George Berkeley (1685-1753) which it once regarded as an attack on its very foundation.

The scientific view of nature as pure materiality was associated with the Newtonian view of space as an absolute void in which things are situated. This attitude of science had, no doubt, ensured its speedy progress; but the bifurcation of a total experience into two opposite domains of mind and matter had forced it, in view of its own domestic difficulties, to consider the problems which in the beginning of its career it completely ignored. The criticism of the foundations of the mathematical sciences had fully disclosed that the hypothesis of a pure materiality, an enduring stuff situated in an absolute space, was unworkable. Was space an independent void in which things were situated and which would remain intact if allthings were withdrawn?

Iqbal, then, cited the example of the ancient Greek philosopher Zeno who approached the problem of space through the question of movement in space. His arguments for the unreality of movement were well known to the students of philosophy, and ever since his days the problem had persisted in the history of thought and received the keenest attention from successive generations of thinkers. Zeno, who took space to be infinitely divisible, argued that movement in space was

\footnotetext{
${ }^{11}$ For example, in 1927 Martin Heidegger (1889-1976) had published his Sein und Zeit [Being and Time] (Tübingen: Max Niemeyer). For further details on Martin Heidegger's conceptions, and concepts, of Time, please refer to Martin Heidegger, History of the Concept of Time:

Prolegomena. Translated by Theodore Kisiel, (Bloomington: Indiana University Press, 1985);

François Raffoul, "Heidegger and the Aporia of History," in Poligrafi: Natural History, vol 16, ns. 61-62 (2011): 91-118; Martin Heidegger, "Der Zeitbegriff in der Geschichtswissenschaft" [The Concept of Time in the Science of History] in Zeitschrift für Philosophie und Philosophie Kritik 161 (1916): 173-188; and Q. Edward Wang, "Time, History, and Dao: Zhang Xuecheng and Martin Heidegger," in Dao: A Journal of ComparativePhilosophy, Vol. I, No. 2, (June2002): 251-276.

${ }^{12}$ Muhammad Iqbal, The Reconstruction of Religious Thought in Islam, 28-61.
} 


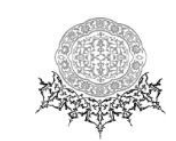

impossible. Before the moving body could reach the point of its destination it must pass through half the space intervening between the point of origin and the point of destination; and before it could pass through that half it must travel through the half of the half, and so on to infinity. We could not move from one point of space to another without passing through an infinite number of points in the intervening space. But it was impossible to pass through an infinity of points in a finite time. $\mathrm{He}$ further argued that the flying arrow did not move, because at any time during the course of its flight it was at rest in some point of space. Thus Zeno held that movement was only a deceptive appearance and that reality was one and immutable. The unreality of movement meant the unreality of an independent space.

Muslim thinkers of the school of al-Ash'ari did not believe in the infinite divisibility of space and time. With them space, time, and motion were made up of points and instants which could not be further subdivided. Thus they proved the possibility of movement on the assumption that infinitesimals did exist; for if there was a limit to the divisibility of space and time, movement from one point of space to another point was possible in a finite time. Ibn Hazm, however, rejected the Ash'arite notion of infinitesimals, and modern mathematics had confirmed his view. The Ash'arite argument, therefore, could not logically resolve the paradox of Zeno.

Of modern thinkers, the French philosopher Henri Bergson (1859-1941) and the British mathematician Bertrand Russell (1872-1970) tried to refute Zeno's arguments from their respective stand points. To Bergson movement, as true change, was the fundamental reality. The paradox of Zeno was due to a wrong apprehension of space and time which were regarded by Bergson only as intellectual views of movement. Zeno's argument was obviously based on the assumption that space and time consisted of infinite number of points and instants. On this assumption it was easy to argue that since between two points the moving body will be out of place, hence motion was impossible, for there was no place for it to occur. The discovery of Georg Cantor (1845-1918) showed that space and time were continuous. Between any two points in space there were an infinite number of points, and in an infinite series no two points were next to each other. The infinite divisibility of space and time meant the compactness of the points in the series; it did not mean that points are mutually isolated in the sense of having a gap between one another.

The reality of movement implied the independent reality of space and the objectivity of nature. But the identity of continuity and the infinite divisibility of space was no solution of the difficulty. Assuming that there was a one to one correspondence between the infinite multiplicity of instants in a finite interval of time and an infinite multiplicity of points in a finite portion of space, the difficulty arising from the divisibility remained the same. The mathematical conception of continuity as infinite series applied not to movement regarded as an act, but rather to the picture of movement as viewed from the outside. The act of movement, that is 


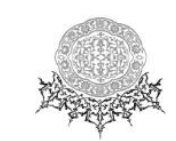

movement as lived and not as thought, did not admit of any divisibility. The flight of the arrow observed as a passage in space was divisible, but its flight regarded as an act, apart from its realization in space, was one and incapable of partition into a multiplicity. In partition lies its destruction, and personally, Iqbal believed that the ultimate character of reality was spiritual.

Looking at Einstein's theory of Relativity from the standpoint that he had taken in these lectures, Iqbal considered that it presented one great difficulty that is the unreality of time. A theory which took time to be a kind of fourth dimension of space must regarded the future as something already given, as indubitably fixed as the past. Time as a free creative movement had no meaning in that theory. It did not pass. Events did not happen; we simply met them. It must not, however, be forgotten that the theory neglected certain characteristics of time as experienced by us; and it was not possible to say that the nature of time was exhausted by the characteristics which the theory did note in the interests of a systematic account of those aspects of nature which could be mathematically treated. Nor was it possible for us laymen to understand what the real nature of Einstein's time was.

It was obvious that Einstein's time was not Bergson's pure duration. Nor could we regard it as serial time, which was the essence of causality as defined by Immanuel Kant (1724-1804). The cause and its effect were mutually so related that the former was chronologically prior to the latter, so that if the former was not, the latter could not be. If mathematical time was serial time, then on the basis of the theory it was possible, by a careful choice of the velocities of the observer and the system in which a given set of events were happening, to make the effect precede its cause.

For Iqbal, time regarded as a fourth dimension of space really ceased to be time. The Russian writer, Piotr Demianovitch Ouspensky (1878-1947), in his book called Tertium Organum (1922), conceived the fourth dimension to be the movement of a three-dimensional figure in a direction not contained in it. Just as the movement of the point, the line and the surface in a direction not contained in them gave us the ordinary three dimensions of space, in the same way the movement of the threedimensional figure in a direction not contained in itself must give us the fourth dimension of space. And since time was the distance separating events in order of their succession and binding them in different wholes, it was obviously a distance lying in a direction not contained in the three-dimensional space. As a new dimension this distance, separating events in the order of succession was incommensurable with the dimensions of three-dimensional space, as a year was incommensurable with St. Petersburg. It was perpendicular to all directions of threedimensional space, and was not parallel to any one of them. Elsewhere, in the same book, Ouspensky described our time-sense as a misty space-sense and argued, on the basis of our psychic constitution, that to one-, two-or three-dimensional beings the 


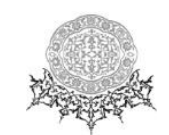

higher dimension must always appear as succession in time. This obviously meant that what appeared to us, three-dimensional beings, as time was in reality an imperfectly sensed space dimension which in its own nature did not differ from the perfectly sensed dimensions of Euclidean space. In other words, time was not a genuine creative movement; and that what we called future events were not fresh happenings, but things already given and located in an unknown space. Yet in his search for a fresh direction, other than the three Euclidean dimensions, Ouspensky needed a real serial time that was a distance separating events in their order of succession. Thus time which was needed and consequently viewed as succession for the purposes of one stage of the argument was quietly divested, at a later stage, of its serial character and reduced to what did not differ in anything from the other lines and dimensions of space. It was because of the serial character of time that Ouspensky was able to regard it as a genuinely new direction inspace. If this characteristic was in reality an illusion, how could it fulfil Ouspensky's requirements of an original dimension?

Iqbal then tried to reach the primacy of life and thought by another route, and carried us a step farther in our examination of experience. The quality of Nature's passage in time was perhaps the most significant aspect of experience which the Qur'ān especially emphasized and which offered the best clue to the ultimate nature of reality. To some of the verses ${ }^{13}$ bearing on the point Iqbal had already drawn our attention, and in view of the great importance of the subject he added a few more:

- 'Verily, in the alternations of night and of day and in all that God hath created in the Heavens and in the earth are signs to those who fear Him.' 14

- 'And it is He Who hath ordained the night and the day to succeed one another for those who desire to think on God or desire to be thankful.' 15

- 'Seest though not that God causeth the night to come in upon the day, and the day to come in upon the night; and that He hath subjected the sun and the moon to laws by which each speedeth along to an appointed goal? ${ }^{16}$,

- 'It is of Him that the night returneth on the day, and that the day returneth on the night,' 17

- 'And of Him is the change of the night and of the day.' 18

There were another set of verses which, indicating the relativity of our reckoning of time, suggested the possibility of unknown levels of consciousness, but Iqbal was content himself with a discussion of the familiar, yet deeply significant aspect of experience alluded to in the verses quoted above.

\footnotetext{
${ }^{13}$ Qur'ān, al-i-Imrān 3:190-91; al-Baqarah 2:164; an-Nūr 24:44.

${ }^{14}$ Qur'ān, Yunus 10:6

${ }^{15}$ Qur'ān, al-Furqān 25:62.

${ }^{16}$ Ibid., Luqmān 31:29.

${ }^{17}$ Ibid., az- Zumar 39:5.

${ }^{18}$ Qur'ān, al-Mu'minūn 23:80.
} 


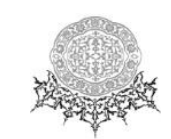

The ontological problem was how to define the ultimate nature of existence. That the universe persists in time is not open to doubt. Yet, since it is external to us, it is possible to be sceptical about its existence. In order to completely grasp the meaning of this persistence in time Iqbal considers that we must be in a position to study some privileged case of existence which is absolutely unquestionable and gives us the further assurance of a direct vision of duration. The perception of things with which one is confronted is superficial and external; but one's perception of his/her own self is internal, intimate, and profound. It follows, therefore, that conscious experience is that privileged case of existence in which we are in absolute contact with reality, and an analysis of this privileged case is likely to throw a flood of light on the ultimate meaning of existence. What do I find when I fix my gaze on my own conscious experience?

There is nothing static in one's inner life; all is a constant mobility, an unceasing flux of states, a perpetual flow in which there is no halt or resting place. Constant change, however, is unthinkable without time. On the analogy of our inner experience, then, conscious existence means life in time. A keener insight into the nature of conscious experience, however, reveals that the self in its inner life moves from the centre outwards. It has two sides which may be described as appreciative and efficient.

On its efficient side it enters into relation with what we call the world of space. The efficient self is the subject of associationist psychology - the practical self of daily life in its dealing with the external order of things which determine our passing states of consciousness and stamp on these states their own spatial feature of mutual isolation. The self here lives outside itself as it were, and while retaining its unity as a totality, discloses itself as nothing more than a series of specific and consequently numerable states. The time in which the efficient self lives is, therefore, the time of which we predicate long and short. It is hardly distinguishable from space. We can conceive it only as a straight line composed of spatial points which are external to one another like so many stages in a journey. But time thus regarded is not true time, accordingto Bergson. Existence in spatialized time is spurious existence. A deeper analysis of conscious experience reveals to us what Iqbal called the appreciative side of the self. With our absorption in the external order of things, necessitated by our present situation, it is extremely difficult to catch a glimpse of the appreciative self. In our constant pursuit of external things, we weave a kind of veil round the appreciative self which thus becomes completely alien to us. It is only in the moments of profound meditation, when the efficient self is in abeyance, that we sink into our deeper self and reach the inner centre of experience. In the lifeprocess of this deeper ego the states of consciousness melt into each other. The unity of the appreciative ego is like the unity of the germ in which the experiences of its 


\section{상}

individual ancestors exist, not as a plurality, but as a unity in which every experience permeates the whole.

There is no numerical distinctness of states in the totality of the ego, the multiplicity of whose elements is, unlike that of the efficient self, wholly qualitative. There is change and movement, but change and movement are indivisible; their elements interpenetrate and are wholly non-serial in character. It appears that the time of the appreciative-self is a single 'now' which the efficient self, in its traffic with the world of space, pulverizes into a series of 'nows' like pearl beads in a thread. Here is, then, pure duration unadulterated byspace. The Qur'ān, alludes to the serial and non-serial aspects of duration inthe following verses:

- 'And put thou thy trust in Him that liveth and dieth not, and celebrate His praise Who in six days created the Heavens and the earth, and what is between them, then mounted His Throne; the God of mercy.'19

- 'All things We have created with a fixed destiny: Our command was but one, swift as the twinkling of an eye. ${ }^{20}$

If we look at the movement embodied in creation from the outside, that is to say, if we apprehend it intellectually, it is a process lasting through thousands of years; for one Divine day, in the terminology of the Qur'ān, as of the Old Testament, is equal to one thousand years. From another point of view, the process of creation, lasting through thousands of years, is a single indivisible act, 'swift as the twinkling of an eye.' It is, however, impossible to express this inner experience of pure duration in words, for language is shaped on the serial time of our daily efficient self.

Iqbal, then, gives the example from science. According to physical science, the cause of one's sensation of red is the rapidity of wave motion the frequency of which is 400 billion per second. If one could observe this tremendous frequency from the outside, and count it at the rate of 2,000 per second, which is supposed to be the limit of the perceptibility of light, it would take more than six thousand years to finish the enumeration. Yet in the single momentary mental act of perception a person holds together a frequency of wave motion which is practically incalculable. That is how the mental act transforms succession into duration. The appreciative self, then, is more or less corrective of the efficient self, in as much as it synthesizes all the 'heres' and 'nows' - the small changes of space and time, indispensable to the efficient self - into the coherent wholeness of personality.

Pure time, then, as revealed by a deeper analysis of our conscious experience, is not a string of separate, reversible instants; it is an organic whole in which the past is not left behind, but is moving along with, and operating in, the present. And the future is given to it not as lying before, yet to be traversed; it is given only in the

\footnotetext{
${ }^{19}$ Qur'ān: al-Furqān 25:58-59.
}

${ }^{20}$ Qur'ān: al-Qamar 54:49-50. 


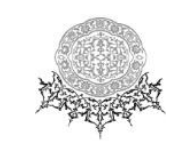

sense that it is present in its nature as an open possibility. It is time regarded as an organic whole that the Qur'ān describes as Taqdīr or the destiny, that is the time regarded as prior to the disclosure of its possibilities. Time freed from the net of causal sequence-the diagrammatic character which the logical understanding imposes on it. In one word, it is time as felt and not as thought and calculated.

Time regarded as destiny forms the very essence of things. The Qur'ān says, 'God created all things and assigned to each its destiny.' The destiny of a thing then is not an unrelenting fate working from without like a task master; it is the inward reach of a thing, its realizable possibilities which lie within the depths of its nature, and serially actualize themselves without any feeling of external compulsion. Thus the organic wholeness of duration does not mean that full-fledged events are lying, as it were, in the womb of reality, and drop one by one like the grains of sand from the hour-glass. If time is real, and not a mere repetition of homogeneous moments which make conscious experience a delusion, then every moment in the life of reality is original, giving birth to what is absolutely novel and unforeseeable. 'Everyday doth some new work employ Him,' says the Qur'ān. To exist in real time is not to be bound by the fetters of serial time, but to create it from moment to moment and to be absolutely free and original in its creation. In fact, all creative activity is free activity. Creation is opposed to repetition which is a characteristic of mechanical action. That is why it is impossible to explain the creative activity of life interms of mechanism.

Science seeks to establish uniformities of experience that is the laws of mechanical repetition. Life with its intense feeling of spontaneity constitutes a centre of in determination, and thus falls outside the domain of necessity. Hence science cannot comprehend life. The biologist who seeks a mechanical explanation of life is led to do so because he confines his study to the lower forms of life whose behaviour discloses resemblances to mechanical action. If he studies life as manifested in himself that is his own mind freely choosing, rejecting, reflecting, surveying the past and the present, and dynamically imagining the future, he is sure to be convinced of the inadequacy of his mechanical concepts. On the analogy of our conscious experience, then, the universe is a free creative movement. But how can we conceive a movement independent of a concrete thing that moves? The answer, for Iqbal, was that the notion of 'things' is derivative. We can derive 'things' from movement; we cannot derive movement from immobile things. If, for instance, we suppose material atoms, such as the atoms of Democritus, to be the original reality, we must import movement into them from the outside as something alien to their nature. Whereas, if we take movement as an original; static things may be derived from it.

In fact, physical science had reduced all things to movement. The essential nature of the atom in modern science was electricity and not something electrified. Apart from this, things are not given in immediate experience as things already possessing definite contour, for immediate experience is continuity without any 


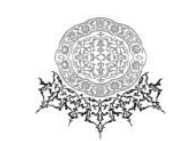

distinctions in it. What we call things are events in the continuity of nature which thought spatializes and thus regards as mutually isolated for purposes of action. The universe which seems to us to be a collection of things is not a solid stuff occupying a void. It is not a thing but an act. The nature of thought according to Bergson is serial; it cannot deal with movement, except by viewing it as a series of stationary points. It is, therefore, the operation of thought, working with static concepts, that gives the appearance of a series of immobilities to what is essentially dynamic in its nature. The co-existence and succession of these immobilities is the source of what we call space and time.

Bergson, however, denied the teleological character of reality on the ground that teleology made time unreal. According to him 'the portals of the future must remain wide open to reality.' Otherwise, it will not be free and creative. No doubt, if teleology means the working out of a plan in view of a predetermined end or goal, it does make time unreal. It reduces the universe to a mere temporal reproduction of a pre-existing eternal scheme or structure in which individual events have already found their proper places, waiting, as it were, for their respective turns to enter into the temporal sweep of history. All is already given somewhere in eternity; the temporal order of events is nothing more than a mere imitation of the eternal mould. Such a view was hardly distinguishable from mechanism which Iqbal had already rejected. In fact, it was a kind of veiled materialism in which fate or destiny took the place of rigid determinism, leaving no scope for human or even divine freedom. The world regarded as a process realizing a preordained goal is not a world of free, responsible moral agents; it is only a stage on which puppets are made to move by a kind of pull from behind.

There was, however, another sense of teleology. From our conscious experience we had seen that to live was to shape and change ends and purposes and to be governed by them. Mental life was teleological in the sense that, while there was no far-off distant goal towards which we were moving, there was a progressive formation of fresh ends, purposes, and ideal scales of value as the process of life grew and expanded. For Iqbal, we become by ceasing to be what we are. Life is a passage through a series of deaths. But there is a system in the continuity of this passage. Its various stages, in spite of the apparently abrupt changes in our evaluation of things, are organically related to one another. The life-history of the individual is, on the whole, a unity and not a mere series of mutually ill-adapted events. The world-process, or the movement of the universe in time, is certainly devoid of purpose, if by purpose we mean a foreseen end - a far-off fixed destination to which the whole creation moves. To endow the world-process with purpose in this sense is to rob it of its originality and its creative character. Its ends are terminations of a career; they are ends to comeand not necessarily premeditated. 


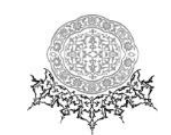

A time-process cannot be conceived as a line already drawn. It is a line being drawn - an actualization of open possibilities. It is purposive only in this sense that it is selective in character, and brings itself to some sort of a present fulfilment by actively preserving and supplementing the past. To Iqbal's mind nothing was more alien to the Qur'ānic outlook than the idea that the universe was the temporal working out of a preconceived plan. According to the Qur'ān, the universe was liable to increase. It is a growing universe and not an already completed product which left the hand of its maker ages ago, and is now lying stretched in space as a dead mass of matter to which time does nothing, and consequently is nothing.

The above discussion took time as an essential element in the ultimate reality, and the next point before Iqbal, therefore, was to consider the argument by John McTaggart (1866-1925) relating to the unreality of time. Time, according to him, was unreal because every event is past, present, and future. Queen Anne's death is past to us, it was present to her contemporaries and future to William III. Thus the event of Anne's death combines characteristics which are incompatible with each other. It is obvious that the argument proceeds on the assumption that the serial nature of time is final. If we regard past, present, and future as essential to time, then we picture time as a straight line, part of which we have travelled and left behind, and part lies yet untraveled before us. This is taking time, not as a living creative moment, but as a static absolute, holding the ordered multiplicity of fully-shaped cosmic events, revealed serially, like the pictures of a film, to the outside observer.

We can indeed say that Queen Anne's death was future to William III, if this event is regarded as already fully shaped, and lying in the future, waiting for its happening. But a future event cannot be characterized as an event. Before the death of Anne, the event of her death did not exist at all. During Anne's life the event of her death existed only as an unrealized possibility in the nature of reality which included it as an event only when, in the course of its becoming, it reached the point of the actual happening of that event. The answer to McTaggart's argument was that the future existed only as an open possibility, and not as a reality. Nor can it be said that an event combines incompatible characteristics when it is described both as past and present. When an event $\mathrm{X}$ does happen it enters into an unalterable relation with all the events that have happened before it. These relations are not at all affected by the relations of $X$ with other events which happen after $X$ by the further becoming of reality. No true or false proposition about these relations will ever become false or true. Hence there is no logical difficulty in regarding an event as both past and present. However, Iqbal had to confessthat the point was not free from difficulty and required further thinking. It was not easy to solve the mystery of time. Quoting Saint 


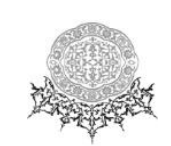

Augustine, 'If no one questions me of time, I know it: if I would explain to a questioner I know it not. 21

Personally, Iqbal was inclined to think that time was an essential element in reality. But real time was not serial timeto which the distinction of past, present, and future was essential; it was pure duration that is change without succession, which McTaggart's argument did not touch. Serial time was pure duration pulverized by thought- a kind of device by which reality exposes its ceaseless creative activity to quantitative measurement. It isin this sense that the Qur'ān says; 'And of Him is the change of the night and of the day.'

\section{Conclusion}

This paper, using Muhammad Iqbal's works, especially The Reconstruction of Religious Thought in Islam dealt with the question of time, history, and historical time in his thought, particularly how he actually distinguished 'the past' from 'the present' and 'the future,' and how he constructed their interrelationships.

As Souleymane Bachir Diagne ${ }^{22}$ asserts ${ }^{23}$ Iqbal's philosophy is a response to those who consider Islam a fatalistic doctrine of predestination. Fatalism is a kind of self-dispossession resting on a cosmology that envisions a closed universe in which time is fixed and the future predetermined. Quite simply, the future comes stocked and ready to go, a fixed and inevitable order of events that can thus be seen as binding and limiting God's creative activity. This is basically the cosmology of the astrologer, for whom the only view that can be taken of time is assured foresight of an inevitable future - a view that comes from an understanding of time as being ultimately connected with space. 'Your ink, that's you,' Iqbal writes, in response to the fatalistic metaphor that presents human destiny as pre-written with an ink that is said to have already dried up. Bergson remarks that we always think time by using spatial metaphors - the river, the geometrical line, and so on. But a great deal is at stake in the 'mere' use of such metaphors: our usual conception of time is serial, cinematic rather than dynamic, and our geometrical notion of it tends, as Iqbal says, 'to deprive time of its living historical character, and to reduce it to a mere representation of space.'

When time is conceived as merely the space separating what is from what will be, we get the picture of 'the universe as a collection of finite things, which presents itself as a kind of island situated in a pure vacuity to which time, regarded as a series of mutually exclusive moments, is nothing and does nothing.' For Iqbal, the

\footnotetext{
${ }^{21}$ St. Augustine, Confessions, Translated by F. J. Sheed, (Indianapolis: Hackett Publishing Company Inc., 2006)

${ }^{22}$ Souleymane Bachir Diagne, "Bergson in the Colony. Intuition and Duration in the thought of Senghor and Iqbal," Qui Parle 17, no. 1 (Fall/Winter 2008): 125-145.

${ }^{23}$ Ibid., 141-143.
} 


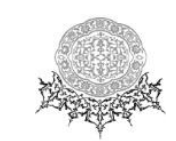

post-Newtonian scientific conception of Physics made it possible to think otherwise, to grasp the cosmos not as a being given in a static view, but as a becoming and a continuously emergent universe. Some true thinking of time as such will be introduced into our world picture.

Iqbal offers as a point of departure an interpretative reading of the Qur'ānic text. Throughout the Reconstruction, he quotes many verses that convey the notion of the continued creation of a world of permanent innovation as opposed to the idea of a finite, achieved act of creation that produced the world semel factis, once and for all. For example, to quote other Qur'ānic passages, 'He [God] adds to His creation what He wills," ${ }^{24}$ or 'Say, - go to the earth and see how God hath brought forth all creation: Hereafter will He give it another birth. ${ }^{25}$ In addition to these citations, he also recalls the prophetic $(S A W)$ saying, 'Do not vilify time, for time is God.'

\section{Bibliography}

Bambach, Charles. "The Time of the Self and the Time of the Other." History and Theory 50 (2011): 254-269.

Bevernage, Berber. "Time, Presence, and Historical Injustice." History and Theory 47 (2008): 149-167.

Bevernage, Berber. "We Victims and Survivors Declare the Past to be in the Present': Time, Historical (In) Justice and the Irrevocable." Ph.D. Thesis. Ghent: University of Gent, Faculty of Arts and Philosophy, 2009.

Chakrabarty, Dipesh. Provincializing Europe. Postcolonial Thought and Historical Difference. Princeton: Princeton University Press, 2000.

Conrad, Sebastian. "What Time is Japan? Problems of Comparative (Intercultural) Historiography." History and Theory 38 (1999): 67-83.

Diagne, Souleymane Bachir. "Bergson in the Colony. Intuition and Duration in the Thought of Senghor and Iqbal.” Qui Parle 17 no. 1 (2008):125-145.

Fabian, Johannes. Time and the Other. How Anthropology Makes its Object. New York: Columbia University Press, 2002.

Fay, Brian. "Hammer Time.” In History and Theory 52 (2013): 1-19.

Hammer, Espen. Philosophy and Temporality from Kant to Critical Theory. Cambridge: Cambridge University Press, 2011.

Hartog, Fançois. Régimes d'Historicité, Présentisme et Expériences du Temps. Paris: Le Seuil, 2003.

\footnotetext{
24al-Qur'ān, Fātir: 35:1

${ }^{25}$ al-Qur'ān, al- Ankabūt: 29:19.
} 


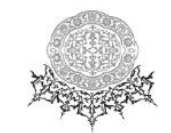

Heidegger, Martin. "Der Zeitbe griff in der Geschichtswissenschaft." [The Concept of Time in the Science of History] in Zeitschrift für Philosophie und Philosophie Kritik 161 (1916): 173-188.

Heidegger, Martin. History of the Concept of Time: Prolegomena. Translated by Theodore Kisiel. Bloomington: Indiana University Press, 1985.

Hölscher, Lucian. Semantik der Leere. Grenzfragen der Geschichtswissenschaft (Semantics of emptiness. Frontier Questions of History) Göttingen: Wallstein Verlag, 2009.

Hoy, David Couzens. The Time of Our Lives: A Critical History of Temporality. London: MIT Press, 2009.

Hunt, Lynn. Measuring Time, Making History. Budapest: Central European University Press, 2008.

Iqbal, Muhammad. The Reconstruction of Religious Thought in Islam. New Delhi: Kitab Bhavan, 1998.

Jordheim, Helge. “Against Periodization: Koselleck's Theory of Multiple Temporalities." History and Theory 51 (2012): 151-171.

Kasabova, Anita. "Memory, Memorials, and Commemoration." In History and Theory 47 (October 2008): 331-350.

Koselleck, Reinhart. Futures Past: On the Semantics of Historical Time, transl. Keith Tribe. Cambridge, Mass.: MIT Press, 1985.

Koselleck, Reinhart. Zeitschichten: Studien zur Historik (mit einem beitrag von Hans-Georg Gadamer) [Time strata: Studies on History (with a contribution by Hans-Georg Gadamer]. Frankfurt: Suhrkamp Verlag, 2000.

Koselleck, Reinhart. The Practice of Conceptual History: Timing History, Spacing Concepts, transl. Todd Samuel Presner et al. Stanford: Stanford University Press, 2002.

Lebovic, Nitzan. "The Sovereignty of Modern Times: Different Concepts of Time and the Modernist Perspective." History and Theory 49 (2010): 281-288.

McAdam, Doug, and Sewell Jr., William H. "It's About Time: Temporality in the Study of Social Movements and Revolutions." In Aminzade, Ronald et al. Silence and Voice in the Study of Contentious Politics. Cambridge: Cambridge University Press, (2001): 80-126.

Miller, Tyrus. Given World and Time: Temporalities in Context. Budapest: CEU Press, 2008.

Raffoul, François. "Heidegger and the Aporia of History." Poligrafi: Natural History 16, no. 61-62 (2011):91-118. 


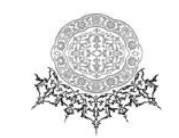

Wang, Edward Q. "Time, History, and Dao: Zhang Xuecheng and Martin Heidegger." Dao: A Journal of Comparative Philosophy 1, no. 2 (2002): 251276.

Yourgrau, Palle. A World without Time: The Forgotten Legacy of Gödel and Einstein. New York: Basic Books, 2004.

Zammito, John. "Koselleck's Philosophy of Historical Time(s) and the Practice of History." History and Theory 43 (2004):.124-135. 